NBER WORKING PAPER SERIES

MORTGAGE REVENUE BONDS: TAX EXEMPTION
WITH A VENGEANCE

Patric H. Hendershott

Working Paper No. $\underline{447}$

NATIONAL BUREAU OF ECONOMIC RESEARCH

1050 Massachusetts Avenue

Cambridge MA 02138

February 1980

This research is funded by the Office of Policy

Development and Research of the Department of HUD through contract $\mathrm{H}-2893$ extended to the Urban Institute. Numerous helpful suggestions were offered by Harvey Galper and others in the Office of Tax Analysis, Department of the Treasury, at a seminar presented there. The research reported here is part of the NBER's research program in Taxation and Financial Markets and Monetary Economics. Any opinions expressed are those of the author and not those of the National Bureau of Economic Research. 
Mortgage Revenue Bonds: Tax

Exemption With a Vengeance

\begin{abstract}
This paper presents calculations of the impacts of two levels of mortgage revenue bonds (MRBs) on: (1) yields on home mortgages, tax-exempt bonds and taxable bonds, (2) the allocation of the American fixed capital stock among residential (by three tax brackets), business, and state and local capital, (3) the productivity of this aggregate stock, and (4) the federal deficit. The levels of MRBs analyzed are $\$ 40$ billion and the maximum permitted by the realities of the market place. The latter is estimated to be $\$ 440$ billion or over half of regular home mortgages outstanding.

Limited levels of MRBs directed solely at "lower" income housing would not have any clear impact on productivity. An unlimited volume would generate an estimated annual productivity loss of $\$ 3$ billion. Assuming a 4 percent discount rate, the present value of this stream is $\$ 75$ billion.
\end{abstract}

Patric H. Hendershott Krannert School of Management Purdue University West Lafayette, Indiana 47907

(317) $493-1884$ 


\section{Mortgage Revenue Bonds: Tax Exemption with a Vengeance*}

Patric H. Hendershott

Purdue University and NBER

Many issues have been raised in the current debate regarding the merits of tax-exempt mortgage revenue bonds. There has been some worry about the impacts of these bonds on profits of investment bankers (positive) and mortgage lenders (negative) and much concern over the impacts on the federal deficit and the state and local borrowing rate (both rise). I/ However, the most important economic issue -- the effect on the allocation and productivity of the American nonfinancial capital stock -- has yet to be addressed. This is the most important issue because a productivity loss (or gain) is a net loss (or gain) to society, and unlimited issues of mortgage revenue bonds could generate a significant loss. In contrast, changes in profits, interest rates, and tax receipts are a wash; some economic units/sectors gain while others lose. Moreover, the net redistributions are likely to be small. For example, higher income households would likely gain the most from a rise in yields on municipal securities, but they would also bear the heaviest burden of increases in tax rates needed to offset potential shortfalis in Treasury tax receipts.

* This research is funded by the Office of Policy Development and Research of the Department of HUD through contract H-2893 extended to the Urban Institute. Numerous helpful suggestions were offered by Harvey Galper and others in the Office of Tax Analysis, Department of Treasury, at a seminar presented there.

$1 /$ General discussions are contained in the Congressional Budget office (1979), Thygerson, Melton and Parliment (1978), and Tuccillo and Weicher (1979). Kormendi and Nagle (1979) restrict themselves to estimates of lost Treasury tax revenues. 
Under current American tax law, overinvestment in owner-occupied housing relative to business, especially corporate, capital would exist even in the absence of inflation. This follows from the fallure to tax imputed rental income from owner-occupled housing and the double taxation of income from corporate capital. As a result, the investment hurdle rate or user cost of capital is lower for housing than for other private capital goods; resources are invested in housing earning a lower rate of return than is available on potential investments in business capital. Inflation aggravates this distortion because real after-tax debt rates decline and housing is much more heavily debt-financed than is business capital. 2/ A recent estimate of the annual productivity or efficiency loss from this distortion is $\$ 12$ billion [Hendershott and $\mathrm{Hu}(1980)$ ]. Substantial usage of tax-exempt mortgage revenue bond financing would increase this loss by causing a further substitution of less productive housing for more productive business (and state and local) capital. The substitution follows from the subsidization of the cost of home mortgage financing and an increase in the borrowing rates of businesses and state and local governments.

This brief discussion also suggests that the channels through which mortgage revenue bonds affect the federal deficit need to be widened. The substitution of housing, the income from which is not taxed and the financing costs of which are tax deductible, for either business capital, the income from which is taxed, or state and local capital, the financing of which is not deductible, will clearly reduce tax revenues. Also, an increase in taxable bond rates will raise the cost of financing the federal debt. Neither of these effects have been considered in earlier analysis.

\footnotetext{
2/The primary cause of the decline in real after-tax debt yields is another distortion in the tax law: the use of historical cost accounting in the valuation of depreciation and inventory expenses [Hendershott (1979)].
} 
The present paper will provide estimates of the productivity loss and increase in federal deficit caused by the growth in tax-exempt mortgage revenue bonds (MRBs). Two alternative levels of MRBs are considered: a legislatively constrained (to provide only lower income housing) volume of $\$ 40$ billion and an unconstrained (except for the realities of the market place) volume. The former is five percent of the roughly $\$ 800$ billion late-1979 stock of home mortgages outstanding and is one of the limitations being considered by Congress. The latter is the volume of MRBs which raises the tax-exempt yield to the point that it is no longer possible to offer MRB-financed home mortgages at yields below those generally available in the market place.

The analysis of these two volumes of MRBs encompasses three tasks:

(1) Determination of the impact on the financial markets. of particular interest are the effects on the yields on tax-exempt securities, home mortgages, and other taxable securities, but the changes in sectoral balance sheets are also needed to obtain a full picture of the workings of MRBs and to compute the impact on the federal deficit.

(2) An assessment of the impact of changes in capital market rates on the user costs of capital or investment hurdle rates for owner-occupied housing and other components of nonfinancial capital and thus on the composition of the nonfinancial capital stock. The impact of the latter change on the productivity of the American economy can then be calculated.

(3) A measure of the impact of financial market changes and the reallocation of the nonfinancial capital stock on the federal budget. Treasury tax receipts will be lowered by the substitution of tax-exempt for taxable financing, by the simultaneous issue of mortgages and purchase of tax-exempts, and by 
Increases in owner-occupled housing at the expense of business and state and local capital. Treasury interest payments will vary with changes in Treasury borrowing rates.

The impacts of MRBs on the financial markets and real capital allocation are obviously simultaneously determined, and this determination is developed in the appendix. The body of the text is devoted to explaining and summarizing the nature of the impacts. Those on interest rates and the allocation and productivity of the capital stock are considered in Sections I and II, respectively. The impact on the federal budget is deduced in Section III where changes in the full sectoral balance sheets are also presented. A concluding section summarizes the findings.

\section{Impact on Interest Rates}

Table 1 presents hypothetical yields on long-term tax-exempt, corporate and home mortgage securities under various assumptions regarding the level of mortgage revenue bonds (MRBs). Relationships (ratios or spreads) between the yields are also shown. The ylelds listed in the first row approximate 1979 (pre October) values. The second row contains likely yields under the assumption of a significant, but legislatively constrained, volume of MRBs. The last row illustrates a pattern of yields that might exist when the only constraints on MRBs are the realities of the market place.

The relationships among yields in 1979 are abnormal relative to historical experience. The 1979 ratio of tax-exempt ylelds to taxable ylelds (column 5) 


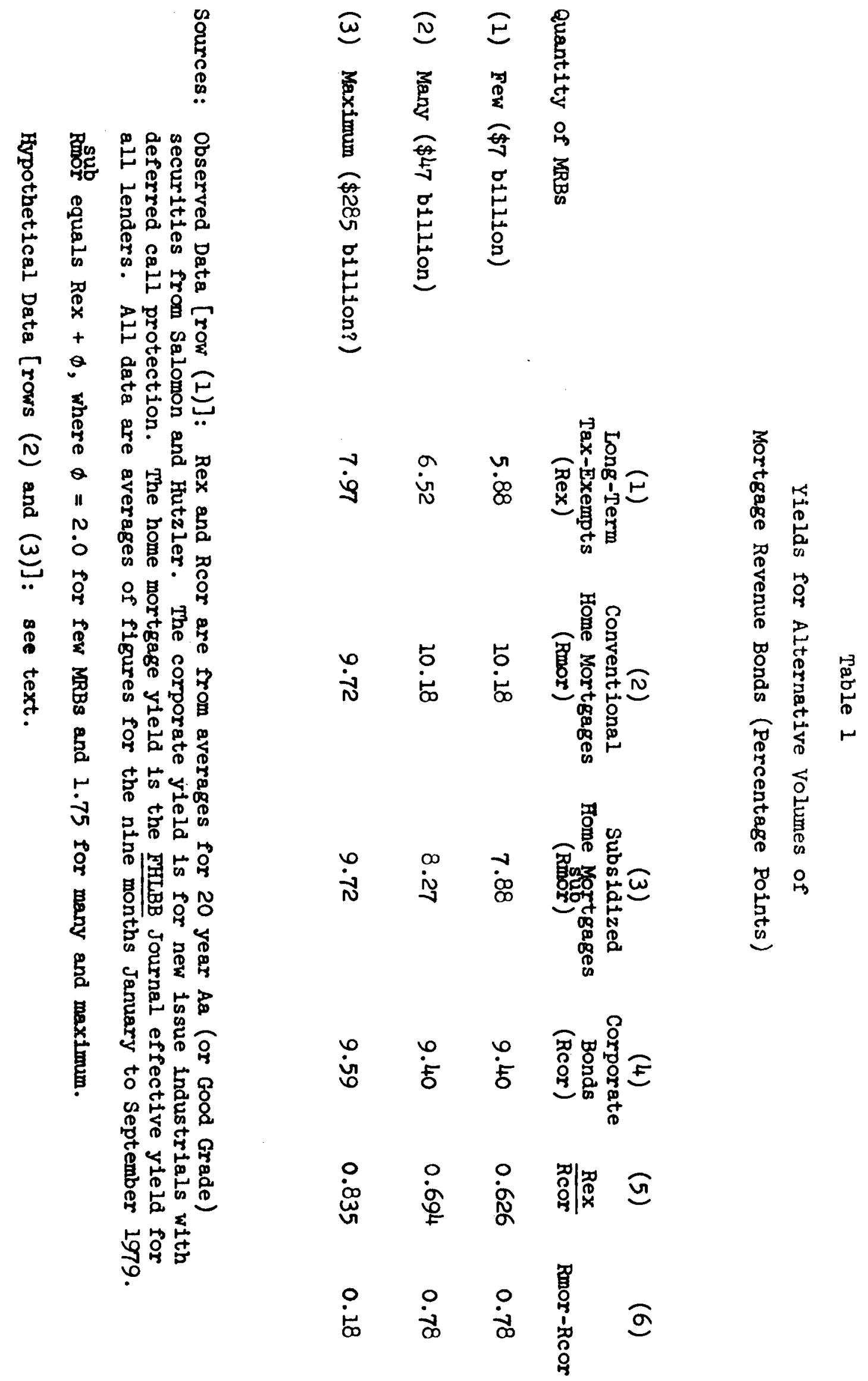


is low (the "normal" ratio during the past decade was about 0.7 ), and the spread between conventional mortgage rates and yields on corporate bonds (column 6) is high (the spread during the past decade has averaged about a quarter percentage point). The low ratio of exempt to taxable yields can be attributed to the extraordinary purchases of tax exempts by commercial banks and property insurance companies in recent years. The annual rate of net purchases by banks in the 1977 -mid 79 period is greater than all but the 1970-71 years, and purchases by property insurers in 1977-mid 79 are more than double the rate of accumulation in any prior year. These demands can be attributed to the high and rising profits of these institutions [see Hendershott and Koch (1980)]. The large spread between mortgage and bond rates is likely due to the extraordinary inflation-induced boom in the demand for single-family housing [Villani (1978) and Hendershott and Hu (1979)], which is largely financed by mortgage credit, and the absence of a plant and equipment boom, which would be financed by issues of corporate bonds and commercial mortgages. Put another way, mortgages currently contain a premium necessary to cover the costs of issuing mortgage-backed bonds. Finally, note that the subsidized mortgage rate (column 3 ) is 2 percentage points above the yield on tax-exempt securities in the case of few MRBs, and $13 / 4$ percentage points above this yield in the case of constrained and unconstrained MRBs. This spread covers servicing fees, default insurance costs, administrative expenses, and profits. As the volume of MRBs increases, the profit margin, and thus the spread, is likely to decline, but at some point a premium for these bonds might be required.

Other things being equal, MRB issues would certainly raise the tax-exempt yield and the ratio of exempt to taxable yields. The increases in the tax-exempt rate and the rate ratio are necessary to induce investors to purchase the MRBs. 
As MRB outstandings increase initially, households in lower tax brackets are enticed to switch fram taxables to exempts. At some point the rise in exempt rates will be sufficient to induce (1) fully-taxed institutions (comercial banks and property insurers) to purchase additional tax-exempts, (2) partiallytaxed institutions (thrifts and life insurance companies) to purchase exempts for the first time, and (3) middle income households to increase significantly the average loan-to-value ratio on their existing housing in order to finance greater holdings of exempts.

The impact of increases in MRBs on the exempt rate, holding the taxable bond rate constant at Rcor, is illustrated in Figure 1 . All sections of the demand curve, except II, reflect the interest rate sensitivity of households. Section II represents the normal demand by fully-taxed institutions, and section IV encompasses the additional demand of fully-taxed institutions and the new demand by partially-taxed institutions in response to the rate ratio rising above its historically observed level. Section VI is the demand by tax-exempt institutions and households. The negatively-sloped supply schedules reflect the response of state and local government capital outlays to increases in their borrowing rate. Before the increase in MRBs, the exempt rate is Rex and the stock of exempts is EX. An increase in MRBs raises the exempt rate and outstandings, although the latter increases less than the rise in MRBs owing to a reduction in regular tax exempts outstanding. An increase in the taxable bond rate would shift the demand curve upward in Figure 1 and reinforce both the rise in the exempt yield and the reduction in regular tax exempts.

A small increase in MRBs would likely not affect the conventional (unsubsidized) home mortgage rate, again holding the taxable bond rate constant. The volume of conventional financing would decline, but this could be accomplished by a reduction in issues of mortgage-backed bonds and a slight reallocation of portfollos of discretionary investors away from mortgages 

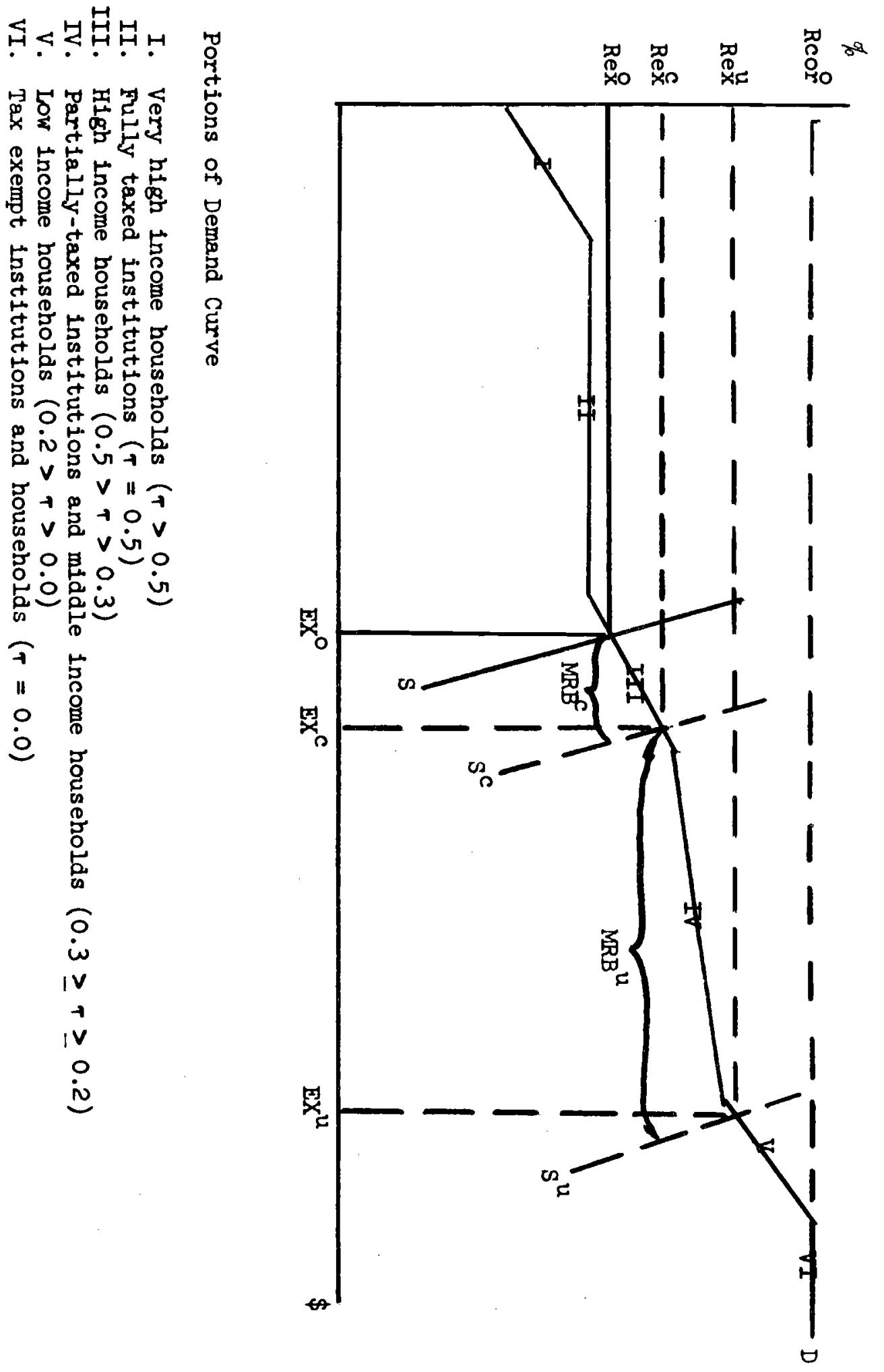

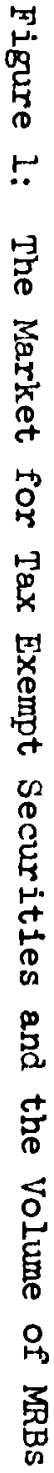


and toward taxable bonds. A large increase in MRBs, in contrast, would greatly reduce conventional financing and eliminate both issues of mortgage-backed bonds and mortgage investments of discretionary investors, leaving only thrifts holding mortgages. Owing to tax-preferences, thrifts would be willing to compete for this reduced demand for mortgage funds by lowering yields [Hendershott (1978)]. As a result, the home mortgage rate would be expected to decline relative to the yields on taxable bonds. If the increase in MRBs were sufficient, even thrifts would abandon the conventional mortgage market and only MRB financing would exist.

Figure 2 illustrates the determination of the conventional home mortgage rate. This rate is on the vertical axis and the volume of conventional (unsubsidized) home mortgage funds is on the horizontal. The demand for funds slopes downward, reflecting a greater demand to finance purchases of houses and other goods at lower mortgage rates. Segment I of the supply curve is the supply by thrifts who will accept a net (of differential servicing costs) yield on mortgages below that on bonds due to the preferential tax treatment afforded mortgages; segment II is the normal demand where net yields are equal. These solid schedules, which are drawn for a given taxable rate (Rcor) and volume of MRBs ( $\mathrm{MRB}^{\circ}$ ), depict the market prior to the increase in MRBs; the conventional rate is Rmor $^{\circ}$, and the volume of nonsubsidized funds is NMOR ${ }^{\circ}$. The Initial yield on subsidized mortgages, $\operatorname{Rex}+2$, is also noted. The third solid schedule indicates how the subsidized rate will rise, owing to both a decline in the profit margin $(\phi)$ of investment bankers and an increase in the tax-exempt yleld, as MRBs expand and conventional financing is reduced. With constrained $18 s u e s$ of MRBs equal to MRB ${ }^{C}$, the demand for conventional financing shifts to the left (shift not shown) to a point such as A, conventional financing declines to $\mathrm{MMOR}^{\mathrm{C}}$, and the subsidized mortgage rate rises 


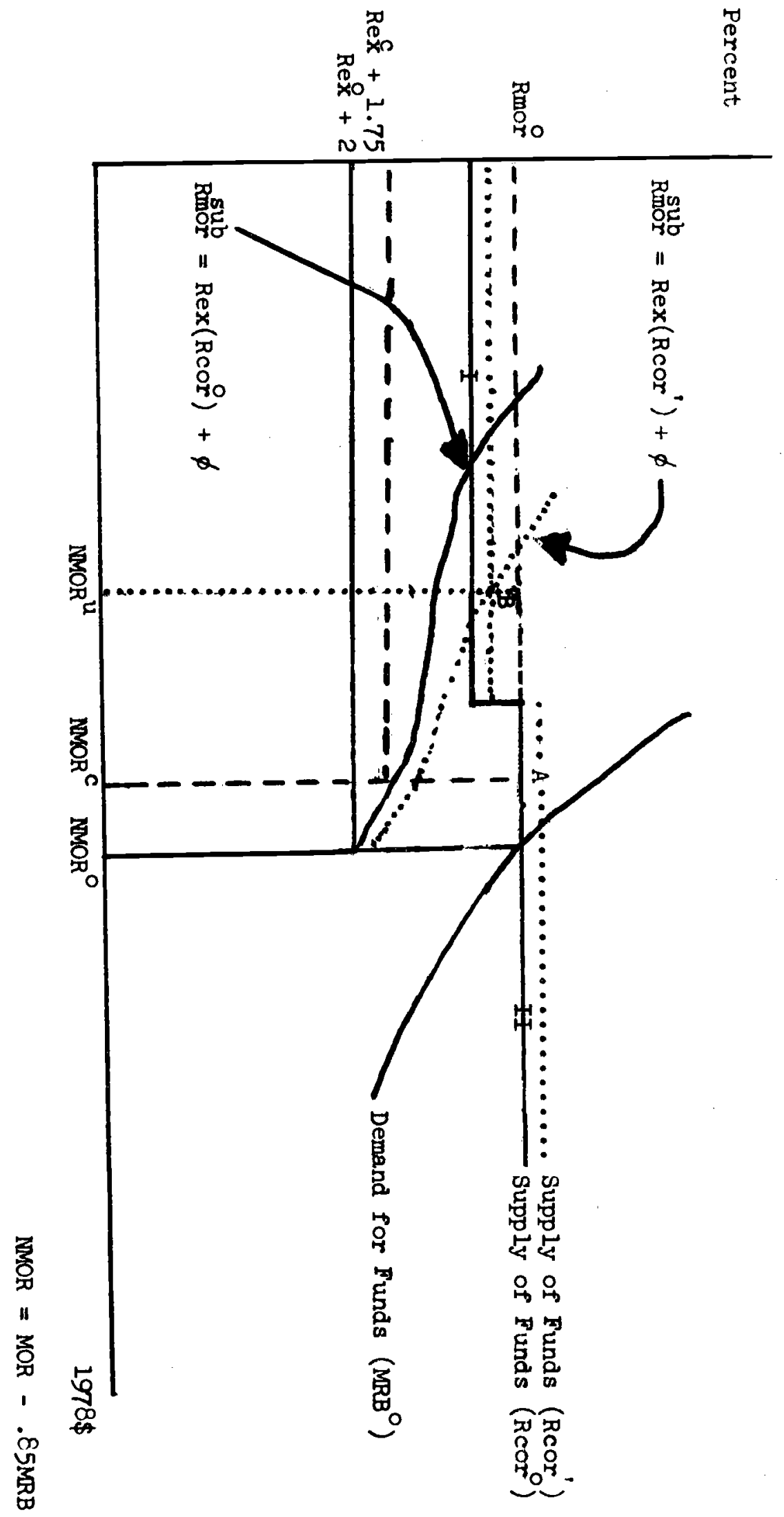

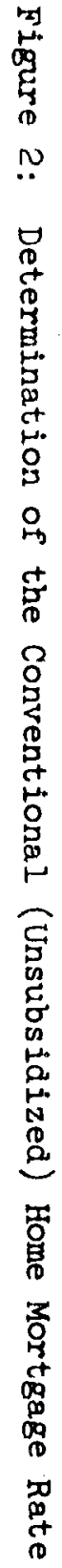


to $\operatorname{Rex}+1.75$. Given that the taxable bond rate has not changed, neither does the conventional mortgage rate.

Next consider unlimited MRBs. The demand for funds shifts to the left (not shown) until either the subsidized mortgage rate equals the conventional rate or conventional financing disappears (which would be true if the Rubr and supply of funds schedules did not intersect). If the taxable rate rises, as seems likely, both the supply of funds and Rubb schedules would shift upward. The result might then be a point like $B$, where conventional financing is $M O R^{u}$, the mortgage rate has fallen relative to the taxable bond rate (only thrifts are financing conventional mortgages), and the subsidized and conventional mortgage rates are equal.

The hypothetical interest rates presented in Table 1 and derived in the appendix are consistent in all respects with this analysis. The tax-exempt rate rises by a small amount ( 64 basis points) with limited MRBs and a large amount (209 basis points) with unlimited MRBs. The taxable bond rate is constant with limited MRBs, but rises by 14 basis points with unlimited MRBs. In the latter case, the subsidized mortgage rate, the exempt rate plus $13 / 4$ percentage points, equals the conventional mortgage rate, and the spread between the latter and the taxable bond rate falls from 78 to 18 basis points.

II. The Allocation and Productivity of the Fixed Capital stock

The observed net (of depreciation) investment hurdle rates or user costs of capital in late 1978 for owner-occupled housing, business fixed capital and state and local structures are listed in the first column of Table 2. These are the net marginal physical products that incremental investments 


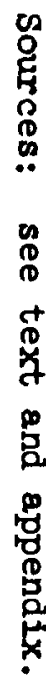

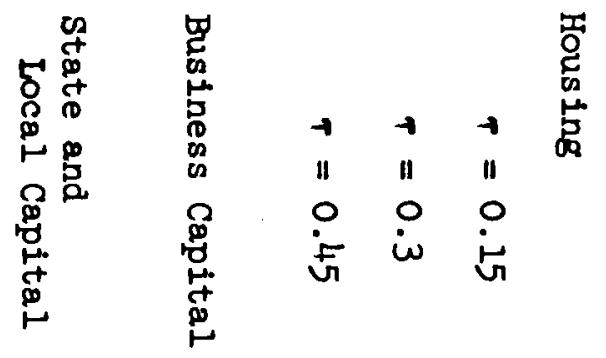

$$
\begin{aligned}
& \begin{array}{lllll}
\dot{8} & \dot{2} & \dot{8} & \dot{8} & \dot{8}
\end{array}
\end{aligned}
$$

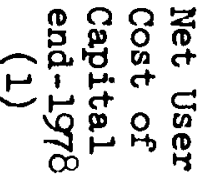

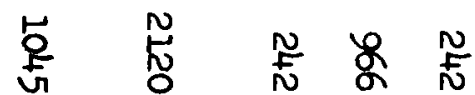

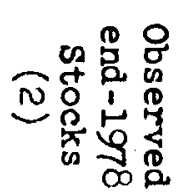

寄

○|d I d 1 点

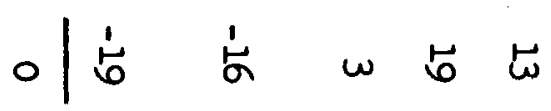

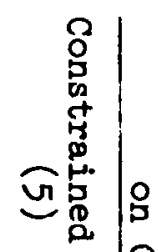

客

:

$$
\text { 这: }
$$

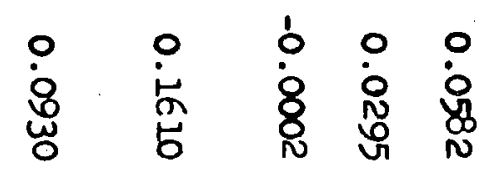

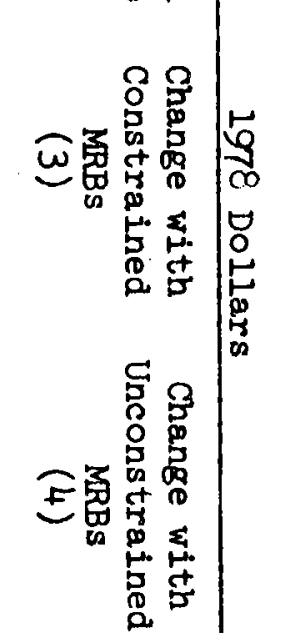

品

息

$\underset{0}{\stackrel{5}{0}}$ 
must promise to earn to be worth undertaking. The hurdle rates are lower for both owner-occupied housing, especially that of households in higher tax brackets, and state and local structures than for business capital. The hurdle rate for the former is low because of (1) the failure to tax the imputed rental income from housing (while allowing the deduction of property taxes and mortgage interest in the computation of the personal income tax base) and (2) the decline in expected real after-tax mortgage rates in response to increases in inflation. The deductibility of expenses also explains why the hurdle rates decline as the tax bracket increases. Tax treatment also explains the relatively low hurdle rate for state and local capital. Neither the income (explicit or implicit) from this capital nor the property itself is taxed, while the interest expense is low (is effectively "deductible") owing to the exemption of interest earned on municipal securities from the federal income tax.

The structure of current (1978) net investment hurdle rates is such that business investment projects promising an expected return of 15 percent are not being undertaken while housing and state and local structures expected to earn less than 10 percent are being constructed. These data make it clear that the efficiency of the fixed capital stock would be increased by lowering the hurdle rate for business capital and raising it for owner-occupied housing, especially for that of households in high tax brackets, and state and local structures. While consumption of housing and local government services would decline, productivity and thus real wages would increase sufficiently to allow an even greater increase in the consumption of other goods and services. The unlimited issuance of MRBs would lower the hurdle rate for housing of households in all tax brackets and raise the rate for state and local and 
business capital. Thus the efficlency of the fixed capital stock would almost certainly be reduced. Note, however, that limited issuance of MRBs to finance low income housing only would not generate efficiency losses if the housing came solely at the expense of state and local capital because the net user cost of the latter is lower than that of the former.

The stock of owner-occupied housing at the end of 1978 was roughly $\$ 1450$ billion. 3/ Given that costs of capital vary by tax bracket, this stock must be distributed among households in different tax brackets. For purposes of the calculations, two-thirds of the stock 1s assigned to those in the 30 percent bracket and one-sixth each to those in the 15 and 45 percent brackets. These stocks and those of businesses and state and local governments are listed in row (2) of Table 2.

Rows (3) and (4) of Table 2 are estimates of the impact of constrained and unconstrained increases in MRBs on the component capital stocks, and rows (5) and (6) contain estimates of the average productivities or rates of return earned (on capital increases) or foregone (on capital decreases). The general procedure employed in these calculations is: ( 1 ) to deduce the impact of the interest rate changes listed in Table 1 on the net and gross user costs of capital, (2) to compute the Impact of changes in gross user costs on the demands for capital, and (3) to average the initial and new net user costs to obtain the average productivities. The details of the calculations are provided in an appendix, but two of the key assumptions are

3/The housing and business capital stock data are current dollar net stocks from Survey of Current Business, August 1979, pp. 62-63. The stock and local capital data is the product of the real stock and price series from the Federal Reserve Board's model data bank. 
worth emphasizing here. First, as is obvious from Table 2, there is no change in the aggregate fixed capital stock, only a reallocation. Second, the assumed elasticities of the demands for owner-occupled housing and business capital with respect to their costs of capital is minus unity, while that of state and local capital is -0.1 . The former are roughly consistentwith empirical estimates; the latter is consistent with the widely held view that state and local capital is insensitive to financing costs (there are no reliable estimates).

In the case of a $\$ 40$ increase in MRBs directed solely at lower income households, housing of these households rises by $\$ 14$ billion at the expense of state and local capital and housing of high income households. The decline in the latter follows from the significant rise in yields on tax-exempt securities which raises the opportunity cost of own-financing of high-income housing. These offsetting capital stock changes occur without any change in either the taxable bond or conventional mortgage rates (these rate changes were constrained to be equal and happened to be zero).

With no constraints on MRBs, the volume increases by $\$ 432$ billion which constitutes an approximate 150 percent increase in outstanding tax exempt debt. This volume of MRBs is market-determined; the tax-exempt rate has risen sufficiently, given the decline in the conventional mortgage rate, so that municipalities can no longer offer subsidized mortgage funds at a rate below that on nonsubsidized private funds. This increase in tax-exempt mortgage financing leads to a sharp reduction in the demand for conventional mortgage financing which lowers the unsubsidized mortgage rate and raises the demand for housing by all households. The increase is less, proportionately, for middle and high income households whose opportunity cost of own financing rises sharply. The $\$ 35$ billion increase in housing ( $2 \frac{1}{2}$ percent of the stock) 
Is at the expense of both state and local and business capital (the taxable bond rate rises by 14 basis points).

The change in the productivity or efficiency of the fixed capital stock is simply the sum of the products of average rates of return and capital stock changes:

$$
\triangle P R O D=\Sigma \bar{c}_{1} \Delta K_{1}
$$

where bars denote the average of net user costs before and after the increases in MRBs and $i$ varies over state and local structures, business capital, and the three tax-bracket classes of owner-occupled housing. Multiplying rows (3) and (5) in Table 2 and suming, a slight \$0.07 billion dollar annual productivity gain is computed for limited MRBs directed solely at low-income households. Higher yielding low-income housing replaces lower yielding highIncome housing and state and local capital. The sum of the products of rows (4) and (6) indicates a $\$ 3.03$ billion annual productivity loss from unlimited MRBs. In this case, low yielding housing replaces higher yielding business and state and local capital. A smaller productivity loss would occur if the demand for state and local capital were more sensitive to its cost of capital than was assumed, if the demand for housing were less sensitive, or If the conventional mortgage rate did not fall as much relative to the taxable bond rate. 4 /

III. The Impact on Balance Sheets and the Federal Budget

An Increase in the stock of MRBs effects the federal budget in three ways. First, and most obviously, investors will now be holding larger quantities of tax-exempt securities and smaller quantities of taxable

$4 /$ To 1llustrate, if the elasticlty of housing were 0.7 instead of 1.0 and the conventional mortgage rate fell by 50 basis points rather than 60 (relative to the corporate bond rate), then the taxable bond rate would rise by only 4 basis points and the productivity loss would be only $\$ 1.66$ billion. 
securities.5/ This will result in reduced Treasury tax revenues. Second, there will be more housing and less business and state and local capital. Because the income from housing (imputed rent) is not taxed, but the financing costs are deductible, this substitution would, at least in the case of unlimited MRBs, lower tax revenues. Third, Treasury borrowing rates will rise hand in hand with increases in corporate borrowing rates in the unlimited MRB case. 6/ This will increase the interest expense of the Treasury. Thus the federal deficit will tend to rise in response to all three of these effects. The purpose of this section is to calculate the amount by which taxes would have to be raised to maintain an unchanged budgetary position in the cases of legislatively constrained and unconstrained MRBs.

The Impact of expanding MRBs on interest rates and the allocation of the nonfinancial capital stock has been deduced above. In order to calculate the impact on the federal deficit, we need to specify the full effect of increases in MRBs on sectoral balance sheets for four sectors: state and local governments, nonfinancial businesses, households, and financial businesses. The top half of Table 3 presents the changes in balance sheets for the case of constrained MRBs. State and local real capital is down by $\$ 6$ billion [Table 2, row (3)] in response to the rise in the exempt rate, and regular tax-exempts are assumed to fall equally. Of the $\$ 40$ billion increase in MRBs, 85 percent is channelled into mortgages and 15 percent into taxable securities (a reserve account). Owner-occupied housing increases to offset

5/There are also changes in the taxable yields, but the impact of these on tax receipts are likely to be quite small because the changes are small and the interest is deductible as well as subject to tax.

6/For evidence to this effect, see Cook and Hendershott (1978). 
Table 3

The Impact of MRBs on Sectoral Balance Sheets

A. Legislatively Constrained Issues

State and Iocal Governments

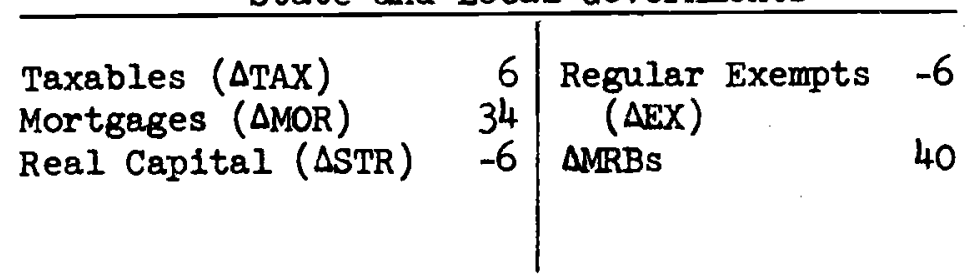

Households (h)

\begin{tabular}{|c|c|c|}
\hline $\begin{array}{l}\text { Exempts ( } \triangle \mathrm{EX}) \\
\text { Taxables ( } \triangle \mathrm{TAX}) \\
\text { Equities ( } \triangle \mathrm{EQ}) \\
\text { Real Capital ( } \triangle \mathrm{HOUS})\end{array}$ & $\begin{array}{r}34 \\
-35 \\
0 \\
6\end{array}$ & Mortgages ( $\triangle M O R) 4$ \\
\hline
\end{tabular}

Nonfinancial Businesses (b)
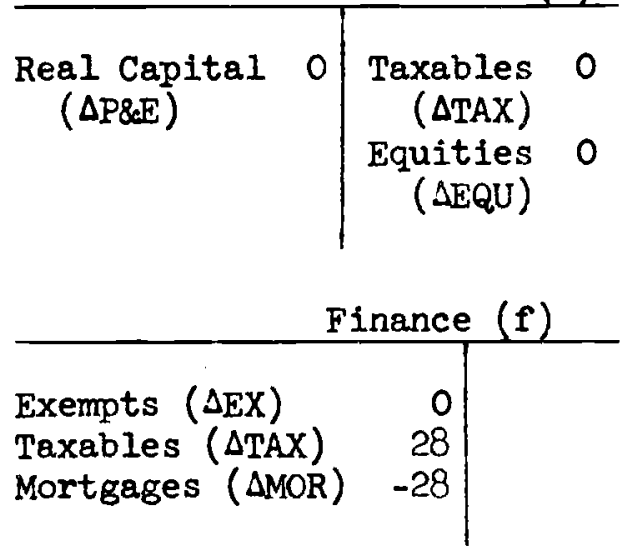

B. Unconstrained Issues

State and Local Governments

\begin{tabular}{|c|c|c|}
\hline$\triangle \mathrm{TAX}$ & 65 & $\triangle E X X$ \\
\hline$\triangle M O R$ & 367 & $\triangle \mathrm{MRBS}$ \\
\hline$\Delta S T R$ & -19 & \\
\hline
\end{tabular}

Households (h)

\begin{tabular}{lr|rr}
\hline & & & \\
$\triangle E X$ & 262 & $\Delta M O R$ & 174 \\
$\triangle \mathrm{TAX}$ & -111 & & \\
$\triangle \mathrm{EQU}$ & -12 & & \\
$\triangle \mathrm{HOUS}$ & 35 & &
\end{tabular}

Nonfinancial Businesses (b)

\begin{tabular}{ll|lr}
\hline$\Delta P \& E$ & -16 & $\Delta T A X$ & -4 \\
& $\Delta E Q U$ & -12
\end{tabular}

Finance ( $f$ )

\begin{tabular}{lr|}
\hline$\triangle E X$ & 151 \\
$\triangle T A X$ & 42 \\
$\triangle M O R$ & -193
\end{tabular}

$$
\begin{aligned}
& \text { Constraints: } \quad \Delta \operatorname{TAX}_{s}+\Delta \operatorname{TAX}_{h}+\Delta \mathrm{TAX}_{\mathrm{f}}=\Delta \mathrm{TAX}_{\mathrm{b}} \\
& \Delta M O R_{s}+\Delta M O R_{f}=\Delta M O R_{h} \\
& \Delta E X_{h}+\Delta E X_{f}=\Delta M R B s-\Delta E X_{s} \\
& \triangle \mathrm{EQU}_{\mathrm{h}}=\Delta \mathrm{EQU_{ \textrm {b } }} \\
& \triangle S T R+\triangle P R E E+\triangle H O U S=0 \\
& \text { Sources equal uses for all sectors. }
\end{aligned}
$$


the decline in state and local capital. Roughly three-quarters of housing is financed by mortgage issues ( $\$ 4$ billion) and one-fourth by liquidating taxable securities. Given that holdings of exempts rise by the $\$ 34$ billion increase in net state and local supply $(\$ 40-\$ 6)$, the sectoral sources equal-uses constraint dictates a $\$ 34$ billion decline in holdings of taxable bonds. Similarly, the changes in the balance sheets of state and local governments and households dictate the finance sectors' $\$ 28$ billion increase in holdings of taxable securities and decrease in mortgages.

The balance sheet changes induced by unconstrained issues of MRBs are given in the lower half of Table 3. The increase in MRBs equals the increased demands by households and financial institutions plus the reduced supply of regular tax exempts. The institutional demand was assumed to be unchanged above because the ratio of exempt to taxable bond yields (0.69) stayed within the normal historically observed range. With unconstrained MRB issues however, the ratio rises to 0.835 . This increase should cause fully-taxed investors in exempts, commercial bank and property insurers, to shield a larger portion of their income with investment in tax-exempts and partially-taxed financial institutions, thrifts and life insurance companies, to invest in tax-exempts for the first time [Hendershott and Koch (1980)]. Fully-taxed institutions are assumed to raise the portion of net income so shielded by 25 percent; thus commercial banks will shield 75 percent of their income, up from 60 percent. This would raise the demand for tax-exempts by these institutions by 25 percent or $\$ 45$ billion at end-1978 values. Partially-taxed institutions would be expected to invest 10 percent of their assets or $\$ 106$ billion in tax-exempts [Hendershott and Koch (1980)]. This gives a total increase in institutional demand of $\$ 151$ billion. Household demand is assumed to rise 
by $1250 \Delta$ (Rex/Rcor) or $\$ 262$ billion. The 1250 coefficient is sharply higher than we have estimated in order to reflect a hitherto unobserved demand by middle income households implicitly financed by sharply higher mortgage debt. 7 Given a reduced supply of regular tax-exempts of $\$ 19$ billion [the decline in state and local capital from Table 3, row (4)], the estimate of the increase in MRBs is $\$ 432$ billion.

The remaining balance sheet changes in the lower half of Table 3 are calculated roughly as above. A major difference is a sharp increase in household mortgage debt as middle income households are assumed to raise their existing mortgage debt by 15 percent of their housing stock to profitably arbitrage between mortgage debt and tax-exempts. The decrease in business capital is reflected in both debt and equity outstanding, and the reduction in equity also appears on the asset side of the household balance sheet.

The change in Treasury net income can be derived by applying tax rates and yields to the balance sheet changes in Table 3 and incorporating some other factors. The change in income is

$$
\begin{aligned}
& \Delta \text { INC }=\tau_{t}^{h}\left(\operatorname{Rcor}^{\circ}\right) \Delta \operatorname{TAX}_{h}+\tau_{e}^{h}\left(\operatorname{Requ}^{\circ}\right) E^{\mathrm{EQU}}{ }_{h} \\
& -\Gamma_{i}{ }_{m}^{1} \operatorname{Rmor}^{1} \Delta M O R^{1}-\Gamma_{i} T_{m}^{1}\left(\operatorname{Rmor}^{\operatorname{sub}^{1}}-\operatorname{Rmor}^{\circ}\right)\left(\Delta M O R_{s}-\Delta M O R_{h}\right)^{i}
\end{aligned}
$$

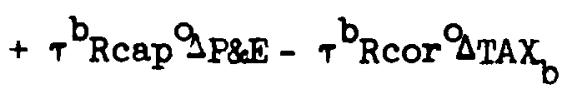

$$
\begin{aligned}
& +\tau^{f} \mathrm{Rmor}^{\circ} \Delta M O R_{f}+\tau^{f} \operatorname{Rcor}^{\circ} \Delta \operatorname{TAX}_{f} \\
& \text { - (I-T)DEBTARcor . }
\end{aligned}
$$

\footnotetext{
$7 /$ The 1250 coefficient is still much lower than the 4800 ( 1978 wealth/0.7) estimated by Kormend 1 and Nagle (1979, Table II, p. 8). The latter seems implausibly large because of the implied effect of the recent decline in the rate ratio from 0.70 to 0.63 on household demand. The 4800 coefficient suggests that this demand would have fallen by $\$ 336$ billion, ceteris paribus, or over 4 times household holdings at the end of 1978. While ceterts partwus is obviously a strong assumption, other things seem unlikely to have shifted the demand function by over $\$ 300$ billion. It would be interesting to see how well the Kormendi-Nagle equation traces out household demand through 1979.
} 
The first line refers to changes in household tax payments owing to changes in financial asset holdings, while the second line reflects changes in payments caused by changes in mortgage interest tax deductions owing to both Increased mortgage debt and the refinancing of existing mortgage debt at the lower subsidized mortgage rate. Lines 3 and 4 refer to changes in tax payments of nonfinancial and financial businesses, and line 5 is the decline in income caused by greater Treasury credit market costs. All quantity items in the equation refer to the balance sheet changes listed in Table 4, except DEBT which is the level of outstanding federal debt not held by trust funds or the Federal Reserve ( $\$ 500$ billion at the end of 1978 ). The initial corporate and mortgage interest rate data are avallable in Table $1 ;^{8}$ other assumed values are $\operatorname{Requ}^{\circ}=0.12$ and $\operatorname{Rcap}^{\circ}=0.11$. The tax rate assumptions applicable to both constrained and unconstrained MRBs are $\tau_{e}^{b}=0.24, T^{b}=0.4$ and $T=0.2$. For constrained MRBs, $\tau_{t}^{h}=0.35$ and $\tau^{f}=0.3$; for unconstrained, $\tau_{t}^{h}=0.25$ and $T^{f}=0.25$.

The estimated changes in Treasury net income are listed in Table 4. Five sources of the changes are delineated: the substitution of exempt securities for taxable securities in investors portfolios, the refinancing of existing mortgages at the lower subsidized mortgage rate (which is an offset to the increase in exempt securities), the increase in owner-occupled housing (the income from which is not taxed but the associated financing charges, including foregone income on own-equity, are deductible), the decline

\footnotetext{
8/ In the constrained MRB case where all the subsidized mortgages go to low Income households, both Rmor and Rint? for these households are calculated as averages of the initial and end subsidized mortgage rates $(0.0788$ and 0.0827 from Table 1 ). Further, all refinancing $\left(\Delta \mathrm{MOR}_{\mathrm{s}}-\Delta \mathrm{MOR}_{h}\right)$ is assumed to be by these households. In the unconstrained case, refinancing is assumed to be proportional to the mortgage debt of the different income classes.
} 
Table 4

Annual Change in Treasury Income to be Recovered

by Tax Rate Changes (billions of $\$$ )

Source

Substitution of Tax

Exempts for Taxables ${ }^{a /}$

Increase in Mortgage Debt

Refinancing of Existing

Mortgage Debtc]

Decline in Business

Capital (and interest

deductions) d

Increased Interest

Expense on Debte/

Total

$-1.05$

Cost per $\$$ of MRBs

$+0.11$

$+0.09$

$--$

$-$

0.026
Constrained MRBs ( $\$ 40$ bil) Unconstrained MRBs $(\$ 432$ bil)

$-4.88$

$+0.27$

$-0.55$

$-0.56$

$-12.60$

0.029

Notes $[$ all refer to equation (2)]:

a/Rows (1) and (4).

b/The first summation in row (2).

c/The second summation in row (2).

d/ Row (3).

e/Row (5). 
in business capital (the income from which is taxed but the associated financing charges are only partially deductible), and the increase in the interest expense on the federal debt. As can be seen, the impact on Treasury annual net income would be significant, one billion per year, in the case of constrained MRBs and enormous, $\$ 12.6$ billion per year, with unconstrained MRBs. The only surprising aspect of Table 4 is the positive impact on Treasury tax receipts of the increase in housing in the case of limited MRBs. This follows from (1) the assumption that all subsidized mortgages were channelled to low tax bracket households and (2) the reduction in housing of higher tax bracket households induced be the increase in the tax-exempt rate, their opportunity cost of own financing. Owing to their higher tax brackets and mortgage rates, the decrease in the tax value of their interest deductions outweighs the Increased tax saving of low income households. The lost revenue per billion dollars of MRBs is quite similar in the two cases, between $\$ 25$ and $\$ 30$ million. This is slightly above the $\$ 22 \frac{1}{2}$ million estimate of the CBO (1979, pp. 47-51).

\section{Summary}

Increases in MRBs raise the tax-exempt yield which, ceteris paribus, reduces the demands for state and local capital and housing of high income households. The latter occurs because the tax-exempt yield is the opportunity cost of own financing for these households. When only limited increases in MRBs are allowed and the funds raised are directed to low income households only, the demand for housing by these households rises by as much as the sum of the demands for housing by high income households and state and local capital falls. There is no tendency for the unsubsidized home mortgage and taxable bond rates to change. There is also virtually no impact on aggregate 
productivity; the net productivity gain owing to the increased housing roughly equals the productivity loss from reduced state and local capital. Finally, the impact on Treasury revenue is not complicated. There are the large, well-understood lost tax recelpts caused by the substitution of exempt debt for taxable debt in asset portfolios and a small gain owing to the refinancing of existing mortgage debt at the lower subsidized rates. The annual cost is $\$ 26$ million per billion dollars of MRBs, and this cost is simply a transfer of funds from some economic units to others.

With no legislative constraints, MRBs would expand until the tax-exempt yield rose so high that it would not be economically feasible to issue additional MRBs and relend the funds at a yield below what households could obtain from conventional sources. This volume of MRBs is estimated to be about $\$ 440$ billion. MRBs of this volume would increase outstanding tax-exempt debt by $1 \frac{1}{2}$ times and replace half of regular home mortgage financing. Because all housing is subsidized, the increase in housing demand exceeds the decline in the demand for state and local capital. As a result the taxable bond rate rises to choke off plant and equipment demand. Thus, housing replaces business and state and local capital, both of which would have earned greater returns than the housing. The estimated annual productivity loss is $\$ 3$ billion. Assuming a real after-tax discount rate of 4 percent, the present value of this loss is $\$ 75$ billion. This is, of course, a net loss to society. The rise in the taxable bond rate results in two additional losses to the Treasury; the cost of servicing the federal debt increases and tax receipts on income from the foregone business capital are lost. However, these additional costs are only about $\$ 3$ million per billion of MRBs. The $\$ 12.6$ billion total cost to the Treasury simply reflects the large volume of MRBs. 
issues. However, it seems rather odd for the federal government to be making such a case. After all, it is federal statutes that are largely responsible for the enormous current differences in investment hurdle rates shown in Table 2. If the federal government is really concerned with productivity losses, as well it should be, there are ample options avallable to it. For example, cessation of the double taxation of corporate dividends and allowance of replacement-cost depreciation would sharply lower the investment hurdle rate for business capital, while limitations on the interest and property tax deductions of households would raise housing hurdle rates for households in higher tax brackets [Hendershott and Hu (1980)]. There is something unseemly about the federal government restricting other governments from playing the same "be good to housing" game that it has perfected over the years and seems so reluctant to give up, in spite of the mounting evidence of the long-run damage being inflicted on the economy.

It is particularly paradoxical for Congress to be simultaneously considering a complete prohibition on mortgage revenue bonds and reactivation of the below-market Tandem interest rate subsidies. Our calculations suggest that no lost productivity would occur with limited MRBs because the additional housing promises to earn as great a return as the state and local capital being lost. In contrast, the Tandem mortgage purchase program, which finances mortgage credit by issuing taxable bonds, would raise taxable rates and crowd out business capital that is more productive than housing. Clearly tax-exempt MRB financing is preferable to taxable bond financing. 


\section{Appendix}

This appendix presents the explicit model and assumptions underlying the calculated changes in interest rates and capital stocks reported in Tables 1 and 2 .

\section{A. Constrained MRBs}

If the relevant production functions for the economy are of the CES form, then the demands for capital after increases in MRBs can be related to the initial demands and the ratios of the initial to new gross costs of capital:

$$
K_{1}^{A}=K_{1}^{O}\left(\frac{c_{1}^{0}+d_{1}}{c_{1}^{A}+d_{1}}\right)^{e},
$$

where $\mathrm{K}_{1}$ refers to HOUS ${ }_{.15}$, HOUS ${ }_{.3}$, HOUS ${ }_{.45}$ (the subscript denoting the tax bracket of the households holding the housing), P\&E, and STR; the A and 0 superscripts refer to after and before the increase In MRBs, respectively; the c's are net user costs of capital; and the d's are depreciation rates. The exponent $e$ is assumed to be 1.0 for all $\mathrm{K}_{1}$ except STR; for STR, $e=0.1$. This assumption is discussed briefly in the text.

The post increase-in-MRB net user costs are related to pre-increase net user costs and changes in the interest rates:

$$
\begin{aligned}
& c_{.15}^{A}=c_{.15}^{0}+1.4[0.75(0.85) \Delta R m o r+0.25(0.85) \Delta R c o r] \\
& c_{.3}^{A}=c_{.3}^{0}+1.4[0.75(0.7) \Delta \text { Rmor }+0.25(0.7) \Delta R c o r] \\
& c_{.45}^{A}=c_{.45}^{0}+1.4[0.9(0.55) \Delta R m o r+0.1 \Delta R e x] \\
& c_{P \& E}^{A}=c_{P \& E}^{0}+1.2 \Delta \text { Rcor } \\
& c_{\text {ATD }}^{A}=c_{C T D}^{0}+1.25 \Delta \operatorname{Rex} .
\end{aligned}
$$


The initial costs of capital reflect the ratio of the capital good price to the general price level in late 1978 based upon a ratio of unity in 1964 . Thus the change in interest rate terms are scaled by the same ratios $(1.4$ for housing, 1.2 for business capital, and 1.25 for state and local structures). For housing, weighted averages of changes in yields on debt and the opportunity cost of own financing are employed. The debt rate is the after-tax mortgage rate $(0.85,0.7$ and 0.55 equal 1 minus the relevant marginal tax rate) and the weight applied to the debt rate is 0.75 for low and medium income households and 0.9 for high income households. The own financing rate is the corporate bond rate for low and medium income households, and the tax-exerpt rate for high income households. The form of the housing cost of capital expressions and the initial values of the $c^{0}$ 's are given in Hendershott and Hu (1979a). The depreciation rate for housing is set at 0.025 which is roughly $1.4(0.0175)$.

The changes in the costs of capital for business and state and local capital are related entirely to changes in the relevant debt rate (the equity rates are assumed to move with the relevant bond rates). The initial business costs of capital are averages of the net costs of capital for corporate structures and equipment reported in Hendershott and Hu (1979b) less 0.015 . The constant is subtracted to account for the lower costs of capital for unincorporated businesses caused by the fact that their equity returns are not taxed at both the firm and personal levels. The depreclation rate is an average of the depreciation rates for equipment and structures adjusted for the price ratio factor: $0.102=1.2\left[\frac{1}{2}(0.13+0.04)\right]$. The initial net user cost of capital for 
state and local structures is taken to be 1.25 (Rex + 0.005). A nominal, rather than real, rate of interest is employed because state and local investment projects financed with revenue bonds must generate initial revenues sufficient to meet nominal debt payments. The depreciation rate is $0.05=1.25(0.04)$.

The $\$ 40$ billion dollar increase in MRBs is assumed to be directed to financing low income housing only. A maximum of $\$ 50$ billion of the $\$ 242$ billion of low income housing is assumed to be eligible for this subsidized financing. Thus HOUS .15 is divided into two components, HOUS .158 , the initial value of which is $\$ 50$ billion, and HOUS $.15 u$, the initial value of which is $\$ 192$ billion, with associated costs of capital $c .15 s^{\text {and } c} .15 u^{\circ}$ The latter are both st1ll defined by equation (6), but $\Delta$ Rmor for $c .15$ s is $\overline{\text { subor }}$ - Rmor, where

$$
\overline{\operatorname{Rub}}=\frac{1}{2}[(\operatorname{Rex}+0.0175)+(\operatorname{Re} \dot{x}+0.02)]
$$

The three equations which can be thought of as determining the three Interest rates are

$$
\begin{aligned}
& r K_{1}^{A}=r K_{1}^{O} \\
& \frac{\operatorname{Rex}}{\operatorname{Rcor}}=\frac{\operatorname{Rex}}{\operatorname{Rcor}}+0.002\left[\Delta M R B-\Delta S T R-\Delta E X_{f}^{O}\right] \\
& \Delta R m o r=\Delta R c o r .
\end{aligned}
$$

The first says that the new and old aggregate fixed capital stocks are equal; the second, an inverted household demand equation, specifies how the rate-ratio must rise to induce households to absorb increases in tax-exempt securities ( $\triangle E X_{f}$ is zero, by assumption, in the limited MRB case), and the third ties the change in the conventional mortgage rate to the change in the corporate bond rate. 


\section{B. Unconstrained MRBs}

Equations (1) through (10) continue to hold with the exception of (7). When tax-exempt rates rise sharply, tax-exempts become more profitable than taxables for investors in the 30 percent tax bracket and 90 percent financing becomes preferable to 75 percent financing. Thus equation (7) becomes

$$
c_{.3}^{A}=c_{.3}^{0}+1.4\left[0.9(0.7) \operatorname{Rmo} \frac{A}{2}+0.1 \operatorname{Re} \frac{A}{x}-0.75(0.7) \operatorname{Rmor}-0.25(0.7) \operatorname{Rcor}\right] .
$$

This same phenomenon suggests that the coefficient in the invested household demand equation be lowered. The 0.002 coefficient in equation (13) is reduced to 0.0008 (see the discussion in note 6 on page 20). Further, $\Delta E X_{f}$ in this equation is now $\$ 151$ billion (see page 19 in the text) and $\triangle \mathrm{MRB}$ is endogenous. MRBs will expand until the conventional and subsidized mortgage rates are equal. Thus equation (11) is replaced by

$$
\operatorname{RmoA}=\operatorname{Rex}+0.0175
$$

Owing to the sharp decline in the demand for conventional mortgage financing, the conventional mortgage rate should decline vis-a-vis the taxable bond rate. Thrifts are assumed to compete for the limited demand by passing the value of their tax preferences along to borrowers. This has been estimated to be worth 60 basis points [Hendershott (1978)]. Thus

$$
\Delta R \operatorname{mof}=\Delta R c 0 \text { A }-0.006 .
$$




\section{References}

Congressional Budget office, "Tax-exempt Bonds for Single-Family Housing," A Study Prepared for the Subcomittee on the City of the Committee on Banking, Finance and Urban Affairs, House of Representatives, $96 \mathrm{th}$ Congress, First Session, U.S. Government Printing office, April 1979.

Cook and Hendershott, "The Impact of Taxes, Risk and Relative Security Supplies on Interest Rate Differentials," Journal of Finance, August 1978.

Hendershott, "Tax Preferences for Thrift Institutions and the Yields on Residential Mortgages and Other Securities," paper prepared for the Office of Tax Analysis, U.S. Department of the Treasury, December 1978.

, The Decline in Aggregate Share Values: Inflation, Taxation Risk and Profitability" (revision of NBaR Working Peper No. 370, July 1979).

Hendershott and Hu, "Government-Induced Biases in the Allocation of the Stock of Fixed Capital in the United States," Chapter 4 in von Furstenberg (ed.) Capital, Efficiency and Growth, Ballinger Publishing Co., 1980.

"Inflation and Extraordinary Returns on Owner-Occupled Housing: Some Implications for Economic Stabilization and Efficiency," (revision of NBER Working Paper No. 383, August 1979).

, "A Model of Optimal Feasible Replacement Investment:

Application to Orders for Producers Durables," presented at a Conference on the Economic Effects of Federal Taxes, Brookings Institutions, October 18, 1979 (to be published in a forthcoming Brookings volume).

Hendershott and Koch, "The Demand for Tax-Exempt Securities by Financial Institutions," Journal of Finance, March 1980.

Kormendi and Nagle, "The Interest Rate and Tax Revenue Effects of Mortgage Revenue Bonds," unpublished, July 1979.

Thygerson, Melton and Parliment, "Considerations Relative to the Issuance of Industrial Development Revenue Bonds for Mortgage Lendings," U.S. League of Savings Associations, Economic Working Paper \#21, 1978.

Tuccillo and Weicher, "Local Mortgage Revenue Bonds," The Urban Institute, May 1979.

Villani, "The Impact of Anticipated and Unanticipated Inflation on House Prices and the Return on Home Ownership," May 1978. 